This is the accepted (post-print) version of the following published article:

Kahu, E. R., Stephens, C. V., Leach, L., \& Zepke, N. (2013). The engagement of mature distance students. Higher Education Research and Development, 32(5), 791-804.

doi:10.1080/07294360.2013.777036

\title{
The engagement of mature distance students
}

Ella R. Kahu, Christine Stephens, Linda Leach, \& Nick Zepke

\begin{abstract}
An increasing proportion of tertiary students are aged 25 and over and many of these students choose to study at a distance in order to more easily combine their studies with their family and work commitments. Higher attrition rates and lower course completion rates for this group highlight the need for a greater understanding of their student experience. To explore whether age and mode of study impact on student engagement, satisfaction, learning, and departure intention, data from the Australasian Survey of Student Engagement (AUSSE) from 1116 first year undergraduate students from a single New Zealand university were analysed. Results confirm the influence of student engagement on both student satisfaction and learning, in particular the importance of a supportive learning environment. The findings suggest that while older and distance students are less likely to engage in active learning strategies with their fellow students, they have a much greater capacity to integrate their learning with their work experience. The finding that these students are as satisfied as the more traditional aged, on campus students suggests that their experience is different but not second rate. Universities need to build on the strengths of these students as well as provide greater opportunities for them to form collaborative relationships with similar students. Limitations stemming from the timing of the survey and the inherent limitations of cross sectional surveys suggest the need for more in-depth longitudinal work to understand the changing nature of engagement for these students and to explore why they engage differently with their studies.
\end{abstract}

Keywords: Adult learning; Distance learning; Student engagement; Work integrated learning

\section{Introduction}

Mature students represent an increasing proportion of tertiary students in many developed countries. In New Zealand in 2010, 33\% of students enrolled in bachelor degrees and 55\% of all students were aged over 24 (Ministry of Education, 2011). These students are more likely to study at a distance: $36 \%$ of students over the age of 25 study extramurally compared to only $8 \%$ of those aged $18-19$ and $17 \%$ of those aged 20-24 (Ministry of Education, 2011). Of particular concern is the higher attrition rate of mature distance students in New Zealand. While course pass rates are similar across the different age groups, completion rates show a dramatic decline across the ages: $79 \%$ of those under $20,48 \%$ of those aged $20-24$, and only $41 \%$ of those 25 and over complete their bachelor degrees within eight years (Ministry of Education, 2011). First year attrition rates show a similar pattern, with older students, particularly those who study part time, the most likely to not return to study after their first year. 
Student engagement is widely considered to be an important predictor of retention and success in higher education (Kuh, 2009b) and may be a useful explanatory factor in mature distance student attrition. While there are a range of perspectives on student engagement, the dominant approach in tertiary education sees student engagement as "both the time and energy students invest in educationally purposeful activities and the effort institutions devote to effective educational practices" (Kuh, Cruce, Shoup, Kinzie, \& Gonyea, 2008, p. 542). It is a multifaceted construct incorporating academic challenge, active learning, enriching educational experiences, supportive learning environment, staff and student interaction and work integrated learning. Engagement theory suggests that both academic and social integration are essential (Tinto, 2006). Engagement is a key indicator of the quality of student experience (Krause, Hartley, James, \& McInnis, 2005) and of institutional performance (Kuh, 2009a) and is positively correlated with a range of student outcomes such as critical thinking, cognitive development, self esteem, student satisfaction, and improved grades and persistence (Kuh, 2009b; Pascarella, Seifert, \& Blaich, 2010). Trowler and Trowler (2010) go so far as to suggest that the "value of engagement is no longer questioned" (p. 9).

\section{Engagement of mature distance students}

Despite their growing numbers, only a few studies have specifically examined the engagement of mature students who study off campus. Studies of mature students have found they are both highly satisfied and highly engaged with their studies (Krause et al., 2005). One American study found that, compared to younger students, mature students scored slightly higher on active learning but slightly lower on enriching educational experiences and supportive campus environment (Southerland, 2010). However, distance education is fundamentally different from traditional on campus learning in terms of course structures, learning approaches, and staff-student interaction (LaPointe \& Reisetter, 2008) hence the need for more focussed research. Chen, Gonyea, and Kuh (2008) found distance students to be generally more engaged than campus based students, except for lower scores on active and collaborative learning. The study compared distance students by age, and found older students engage more in higher order mental activities but are less likely to work with other students.

With the limited research focussing specifically on student engagement of this population, it is important to examine findings on other related aspects of the student experience for mature and distance students including practical and emotional barriers, skills and learning styles, and social interaction. Practical problems, such as role and financial pressures, and emotional struggles all contribute to mature student attrition. Family commitments and ongoing gender role expectations create challenges, particularly for women who struggle to balance their caregiving responsibilities with their studies (Christie, Munro, \& Wager, 2005; White, 2008). Financial stress from the increased costs of study and lost income are also commonly cited challenges for mature students (Reay, Ball, \& David, 2002). In addition to these practical difficulties, adult students often struggle to engage due to feelings of alienation and anxiety. Mature students can feel isolated in a culture that is seen as ageist, not meeting the needs of older students (Gallacher, Crossan, Field, \& Merrill, 2002; Johnson \& Watson, 2004). In addition, many have negative perceptions of themselves as learners, which can create a great deal of anxiety and fear of failure (Mercer \& Saunders, 2004; Stone, 2008; Urquhart \& Pooley, 2007).

Differences in skills and knowledge are likely to impact on mature students' engagement. Firstly, a long absence from education can mean a lack of relevant study skills (Murphy \& Fleming, 2000), 
while less experience with technology can also act as a barrier (Henderson, Noble, \& De GeorgeWalker, 2009). With the shift to web based learning management systems this is particularly problematic for distance students: Previous computer experience and higher computer self efficacy are associated with higher satisfaction and success with online learning (Sitzmann, Kraiger, Stewart, \& Wisher, 2006). The cognitive overload caused by the need to learn course content as well as technology skills may be one of the key reasons for the high attrition of first year distance students (Tyler-Smith, 2006). Secondly, there is a tension between the life experiences and knowledge that mature students bring to their study and the abstract theory that is often taught at university (Henderson et al., 2009; Murphy \& Fleming, 2000). At times this results in the need for un-learning (Johnson \& Watson, 2004; Toynton, 2005).

Interactions with staff and students are an important facet of engagement and the findings with mature students are mixed. On the one hand, family and work commitments combined with the potentially alienating culture of universities can mean less time and desire for social activities resulting in less belonging and the loss of important information that is sometimes shared in informal networks (Christie et al., 2005). On the other hand, mature students engage more actively in the classroom, offering more opinions and asking more questions (Kasworm, 2010; Wasley, 2006). Similarly, mature distance students value discussion forums more, use them to a greater extent (Hoskins \& Hooff, 2005), and post more substantive comments (DiBiase \& Kidwai, 2010), but interact more with staff and less with their fellow students (Rabe-Hemp, Woollen, \& Humiston, 2009). However, mature students may compensate for this reduced social integration by either greater integration in their own personal networks (Donaldson \& Graham, 1999) or greater academic integration (Mannan, 2007).

Differences in learning style and motivation may enhance the engagement of mature distance students. Once through the initial transition, mature students demonstrate more effective approaches to study, in particular deeper learning strategies (Hoskins \& Hooff, 2005; Justice \& Dornan, 2001). They find distance study highly satisfying and are better able to manage it than younger students (Moore, Bartkovich, Fetzner, \& Ison, 2002), possibly because online learning encourages more reflective learning strategies, which adult students are more inclined to use (Hartman, Moskal, \& Dziuban, 2005). In addition, possibly because they tend to be more intrinsically motivated and have made greater sacrifices in order to study, mature students tend to be more committed to their study (Bye, Pushkar, \& Conway, 2007; Hoskins \& Hooff, 2005; Justice \& Dornan, 2001).

\section{Research questions}

The construct of student engagement is increasingly recognised as an important lens for examining student experiences. However, as Krause and Coates (2008) point out, there is a need to study how engagement varies across groups of students. Known differences in the experiences at university of mature students and distance students, as summarised above, suggest that these groups of student may differ in their engagement. Little research has specifically examined the student engagement of mature distance students. The present study aims to address this gap with the following research questions:

1. Which dimensions of student engagement predict satisfaction and learning?

2. How do age and mode of study relate to student engagement and to satisfaction and learning?

3. How do the students who consider leaving the university differ in terms of student engagement or in terms of age and mode of study? 


\section{Method}

\section{Participants}

In 2010, first year undergraduate students enrolled at New Zealand's primary provider of university distance education were surveyed by the University. Invitations to complete either a paper or online version of the Australasian Survey of Student Engagement (AUSSE) were sent to 4042 first year students and completed surveys were received from 1303 (32\%). As the focus of this research is domestic students, 57 overseas students were excluded from the sample, as were those cases with missing responses on the independent variables, age and mode of study. This left a sample size of 1131.

Chi-square tests of independence found students who completed the survey were significantly more likely to be aged under $25\left(\chi^{2}=5.67, d f=1, N=1131, p<.05\right)$, campus based $\left(\chi^{2}=43.25, d f=1, N=\right.$ $1131, p<.001)$, female $\left(\chi^{2}=36.31, d f=1, N=1107, p<.001\right)$, and full time $\left(\chi^{2}=54.01, d f=1, N=\right.$ $1108, p<.001)$ than the student population. However, with the exception of gender where $69.7 \%$ of the sample was female compared to only $60.9 \%$ of the population, these differences were not substantial. For example, $27.1 \%$ of the sample was aged 25 and over compared to $30.4 \%$ of the population.

\section{Measures}

The AUSSE is based on the National Survey of Student Engagement (NSSE) and includes 102 items measuring student and institution activities related to student engagement and demographics. Items are scored on various response scales, which for analysis purposes are converted onto a metric scale from 1 to 100.

Student engagement. The six subscales measuring student engagement are shown in Table 1. Eight items were removed from the standard scales, as they measure behaviours not relevant to first year undergraduate students. Four items within the Academic Challenge (AC) subscale assess hours of study and therefore responses are impacted by whether a student is full or part time. Therefore, as recommended by the developers of the NSSE (National Survey of Student Engagement, 2011), for these four items, the mean of full time students was divided by the mean of part time students and then part time students' scores were multiplied by this ratio and capped at the maximum score of 100 . While not a perfect method of adjustment, it is the best available and is necessary as the scores would reflect poorly on part-time students if left unadjusted. The AUSSE has undergone a range of validation techniques including focus groups, interviews, pilot testing, psychometric modelling, and reliability analyses (Coates, 2010).

Table 1. AUSSE Engagement and Outcome Scales with Cronbach Alpha coefficients from the present sample.

\begin{tabular}{|c|c|c|c|}
\hline Scale & $\begin{array}{l}\# \\
\text { Items }\end{array}$ & $\begin{array}{l}\text { Cronbach } \\
\text { Alpha }\end{array}$ & Description \\
\hline $\begin{array}{l}\text { Academic Challenge } \\
\text { (AC) }\end{array}$ & 10 & $\alpha=.72$ & $\begin{array}{l}\text { Extent to which expectations and assessments } \\
\text { challenge students to learn }\end{array}$ \\
\hline Active Learning (AL) & 5 & $\alpha=.68$ & $\begin{array}{l}\text { Students' collaboration with other students to } \\
\text { actively construct their knowledge }\end{array}$ \\
\hline
\end{tabular}




\begin{tabular}{|c|c|c|c|}
\hline $\begin{array}{l}\text { Student Staff } \\
\text { Interactions (SSI) }\end{array}$ & 4 & $\alpha=.63$ & $\begin{array}{l}\text { Level and nature of students' contact with } \\
\text { teaching staff }\end{array}$ \\
\hline $\begin{array}{l}\text { Enriching Educational } \\
\text { Experiences (EEE) }\end{array}$ & 9 & $\alpha=.57$ & Participation in broadening educational activities \\
\hline $\begin{array}{l}\text { Supportive Learning } \\
\text { Environment (SLE) }\end{array}$ & 6 & $\alpha=.75$ & $\begin{array}{l}\text { Extent to which students feel academically and } \\
\text { socially supported by staff and fellow students }\end{array}$ \\
\hline $\begin{array}{l}\text { Work Integrated } \\
\text { Learning (WIL) }\end{array}$ & 5 & $\alpha=.65$ & $\begin{array}{l}\text { Integration of employment-focused work } \\
\text { experiences into study }\end{array}$ \\
\hline Satisfaction & 3 & $\alpha=.78$ & $\begin{array}{l}\text { Quality of educational experience; quality of } \\
\text { academic advice; would attend same institution } \\
\text { again }\end{array}$ \\
\hline Learning & 15 & $\alpha=.88$ & $\begin{array}{l}\text { Academic skills, such as critical thinking and clear } \\
\text { writing; personal skills such as understanding self } \\
\text { and others }\end{array}$ \\
\hline
\end{tabular}

Outcomes. The two outcome measures, Satisfaction and Learning, and their reliability are also shown in Table 1. According to Gonyea (2005), self-report measures of academic development can be trusted for research purposes providing issues of comprehension, retrieval, judgement, and response are met. The AUSSE's parent survey, the NSSE, was designed to satisfy the conditions by which self report data is considered valid (Kuh, 2001).

Independent and control variables. The key independent variables are age and mode of study. To counter problems of extreme skewness and kurtosis, age was converted to a dichotomous variable: 'Under 25' and '25 and Over'. Students categorised as mixed mode of study were re-categorised as internal as they were able to access campus facilities and therefore cannot be considered distance students. Gender (Tison, Bateman, \& Culver, 2011) and part time attendance (Nelson Laird \& Cruce, 2009) have been shown to influence student engagement and are therefore included as control variables.

\section{Analysis}

Hierarchical multiple regression analyses were conducted to establish which dimensions of engagement predict satisfaction and learning (question one). Gender, attendance, age, and mode of study were entered in these models as control variables. Correlations and descriptive statistics were used to answer the second research question. Finally, t-tests were conducted to answer the final question on departure intention.

\section{Results}

Prior to analysis, the data were examined for missing values and the assumptions of multivariate analysis. The percentage of missing data on the engagement scales was relatively high, ranging from $13.5 \%$ for Enriching Educational Experiences (EEE) to 6.1\% for Active Learning (AL). However, $t$ tests demonstrated that the students with missing values on the scales did not differ significantly in terms of the two outcome variables, Satisfaction and Learning. Using a $p<.001$ criterion for Mahalanobis distance, two multivariate outliers were identified and deleted. In addition, analysis of residuals from the regressions on the engagement scales identified six residual outliers for Satisfaction and seven for Learning. Examination of these cases revealed no clear pattern or explanation and these cases were deleted from the dataset. This left 1116 cases for analysis. Examination of the residual scatter plots demonstrated normality, linearity, and homoscedasticity of the residuals. 


\section{Educational outcomes}

To answer the first research question, Learning and Satisfaction were regressed on the dimensions of engagement, while controlling for gender, age, mode, and attendance. When Satisfaction was the dependent variable, the control variables accounted for $1.3 \%$ of the variance (see Table 2). Gender was a significant predictor indicating females were slightly more satisfied with their university experience than males. In the second model, Engagement explained a further 32.9\%. Three engagement scales were significantly related to Satisfaction. Supportive Learning Environment (SLE) and Work Integrated Learning (WIL) were positively related to Satisfaction, while EEE was negatively related.

Table 2. Summary of Hierarchical Regression with Satisfaction as the Dependent Variable

\begin{tabular}{|c|c|c|c|c|}
\hline \multirow[b]{2}{*}{ Variable } & \multicolumn{2}{|c|}{ Model 1} & \multicolumn{2}{|c|}{ Model 2} \\
\hline & $B$ & $\beta$ & $B$ & $\beta$ \\
\hline Constant & 71.18 & & 30.50 & \\
\hline \multicolumn{5}{|l|}{ Control variables } \\
\hline Gender & -4.76 & $-.11^{\mathrm{a}}$ & -3.77 & $-.09^{b}$ \\
\hline Age group & 3.60 & $.08^{\mathrm{b}}$ & 2.32 & .05 \\
\hline Attendance type & 1.64 & .03 & 3.16 & .07 \\
\hline Mode of study & -2.36 & -.05 & 1.07 & .02 \\
\hline \multicolumn{5}{|l|}{ Engagement subscales } \\
\hline Academic Challenge & & & .03 & .02 \\
\hline Active Learning & & & .07 & .07 \\
\hline Student Staff Interactions & & & .00 & .00 \\
\hline Enriching Educational Experiences & & & -.13 & $-.10^{b}$ \\
\hline Supportive Learning Environment & & & .65 & $.56^{\mathrm{a}}$ \\
\hline Work Integrated Learning & & & .10 & $.10^{\mathrm{b}}$ \\
\hline Adjusted $\mathrm{R}^{2}$ & $.013^{\mathrm{b}}$ & & $.34^{\mathrm{a}}$ & \\
\hline
\end{tabular}

Note: ${ }^{\mathrm{a}} \mathrm{p}<.001,{ }^{\mathrm{b}} \mathrm{p}<.01,{ }^{\mathrm{c}} \mathrm{p}<.05$

The results for the regression of Learning on the dimensions of engagement are shown in Table 3 . The first model accounted for only $3.4 \%$ of the variance in Learning while the second model, including the scales of engagement, accounted for $44 \%$ of the variance. All six scales of engagement were significant predictors.

Table 3. Summary of Hierarchical Regression with Learning as the Dependent Variable

\begin{tabular}{lrrrc}
\hline & \multicolumn{2}{c}{ Model 1 } & \multicolumn{2}{c}{ Model 2 } \\
\hline Variable & B & $\beta$ & B & $\beta$ \\
Constant & 51.05 & & 2.00 & \\
Control variables & & & & \\
$\quad$ Gender & -4.92 & $-.12^{\mathrm{a}}$ & -2.35 & $-.06^{\mathrm{c}}$ \\
$\quad$ Age group & 1.99 & .05 & -1.16 & -.03 \\
$\quad$ Attendance type & -2.44 & -.05 & 1.12 & .03 \\
$\quad$ Mode of study & -5.74 & $-.13^{\mathrm{b}}$ & -3.23 & $-.07^{\mathrm{c}}$ \\
\hline
\end{tabular}


Engagement subscales

Academic Challenge

Active Learning

Student Staff Interactions

Enriching Educational Experiences

Work Integrated Learning

Adjusted $\mathrm{R}^{2}$

$.03^{\mathrm{a}}$

$.44^{\mathrm{a}}$

Note: ${ }^{\mathrm{a}} \mathrm{p}<.001,{ }^{\mathrm{b}} \mathrm{p}<.01,{ }^{\mathrm{c}} \mathrm{p}<.05$

\section{Student engagement}

As shown in Table 4, students aged 25 and over scored slightly higher on WIL and AC but slightly lower on AL and EEE. There was no relationship between age and either Learning or Satisfaction. Distance students scored significantly lower on all engagement subscales, except for WIL, for which they were slightly higher. The strongest of these relationships was between mode of study and AL. Mode of study had no impact on Satisfaction but distance students scored slightly lower on the Learning scale.

Table 4. Bivariate Correlations (Pearsons) and Descriptive Statistics for Study Variables

\begin{tabular}{|c|c|c|c|c|c|c|c|c|c|c|c|c|}
\hline & 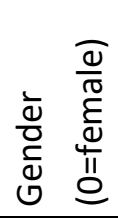 & 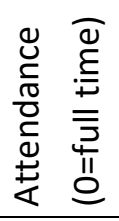 & 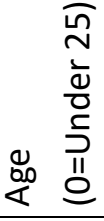 & 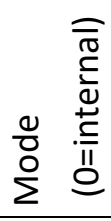 & U & $\vec{\varepsilon}$ & $\bar{n}$ & 岀 & 山 & 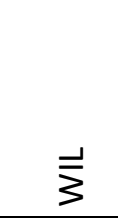 & 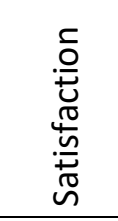 & 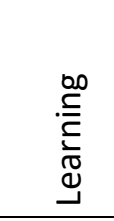 \\
\hline Attendance & .01 & & & & & & & & & & & \\
\hline Age & .03 & $.45^{\mathrm{a}}$ & & & & & & & & & & \\
\hline Mode & -.02 & $.61^{\mathrm{a}}$ & $.51^{\mathrm{a}}$ & & & & & & & & & \\
\hline$A C$ & $-.12^{\mathrm{a}}$ & -.06 & $.10^{\mathrm{a}}$ & .00 & & & & & & & & \\
\hline$A L$ & $-.09^{b}$ & $-.31^{\mathrm{a}}$ & $-.19^{\mathrm{a}}$ & $-.32^{\mathrm{a}}$ & $.38^{\mathrm{a}}$ & & & & & & & \\
\hline SSI & .02 & $-.13^{\mathrm{a}}$ & -.05 & $-.15^{\mathrm{a}}$ & $.36^{\mathrm{a}}$ & $.51^{\mathrm{a}}$ & & & & & & \\
\hline EEE & $-.07^{c}$ & $-.18^{\mathrm{a}}$ & $-.08^{c}$ & $-.12^{\mathrm{a}}$ & $.36^{\mathrm{a}}$ & $.44^{a}$ & $.34^{a}$ & & & & & \\
\hline SLE & -.02 & $-.12^{\mathrm{a}}$ & -.04 & $-.12^{\mathrm{a}}$ & $.30^{\mathrm{a}}$ & $.28^{\mathrm{a}}$ & $.36^{\mathrm{a}}$ & $.38^{\mathrm{a}}$ & & & & \\
\hline WIL & -.03 & $.07^{c}$ & $.12^{\mathrm{a}}$ & $.11^{\mathrm{a}}$ & $.27^{\mathrm{a}}$ & $.28^{\mathrm{a}}$ & $.26^{\mathrm{a}}$ & $.42^{a}$ & $.17^{a}$ & & & \\
\hline Satisfaction & $-.10^{b}$ & .01 & .05 & .00 & $.22^{\mathrm{a}}$ & $.21^{\mathrm{a}}$ & $.22^{\mathrm{a}}$ & $.18^{\mathrm{a}}$ & $.56^{\mathrm{a}}$ & $.19^{a}$ & & \\
\hline Learning & $-.11^{\mathrm{a}}$ & $-.14^{\mathrm{a}}$ & -.04 & $-.14^{\mathrm{a}}$ & $.47^{\mathrm{a}}$ & $.42^{a}$ & $.38^{\mathrm{a}}$ & $.44^{a}$ & $.49^{a}$ & $.38^{\mathrm{a}}$ & $.39^{a}$ & \\
\hline$M$ & & & & & 49.25 & 38.82 & 26.35 & 30.12 & 54.17 & 41.56 & 70.51 & 48.05 \\
\hline SD & & & & & 13.83 & 19.75 & 17.57 & 15.22 & 17.28 & 20.36 & 19.83 & 18.79 \\
\hline
\end{tabular}

Notes: ${ }^{\mathrm{a}} \mathrm{p}<.001,{ }^{\mathrm{b}} \mathrm{p}<.01,{ }^{\mathrm{c}} \mathrm{p}<.05$

Ns range from 924 to 1116 


\section{Departure intention}

Students who had considered leaving study (27\%) did not differ in terms of gender, age, or mode, but were significantly more likely to be full time students $\left(\chi^{2}=4.45, d f=1, N=975, p<.05\right)$. Students who had considered leaving scored significantly lower on three subscales of engagement: SLE ( $M=$ $48.09, S D=17.33$ vs. $M=56.20, S D=16.82, t(971)=6.6, p<.000)$, WIL $(M=38.76, S D=20.13$ vs. $M=42.46, S D=20.23, t(958)=2.5, p=.012)$, and AC $(M=47.39, S D=14.56$ vs. $M=49.62, S D$ $=13.48, t(934)=2.2, p=.029)$. Students who had considered leaving were substantially less satisfied $(M=59.08, S D=22.43)$ than those who had not $(M=74.59, S D=17.09, t(383)=10.2, p<.000)$, and also felt they had learned less $(M=43.60, S D=19.47$ vs. $M=49.34, S D=18.34, t(992)=4.3, p<$ $.000)$.

\section{Discussion}

\section{Educational outcomes}

Student engagement is widely considered to be a critical influence on a diverse range of student outcomes (Trowler \& Trowler, 2010). The findings from the present study support the influence of engagement on satisfaction and student learning, with the six dimensions of engagement explaining $44 \%$ of the variability of student learning. However, student engagement is a multifaceted construct.

Feeling supported by staff and fellow students is the most important predictor of student satisfaction and an important predictor of student learning. The finding that support is more important for satisfaction than for learning parallels Gordon, Ludlum, and Hoey's (2008) study of first year students which found that a supportive campus environment was not predictive of Grade Point Average (GPA) but was a significant contributor to retention. Social support in terms of friendships is potentially particularly important for mature students who often feel they do not fit in the culture of university (Urquhart \& Pooley, 2007). Students need to feel that they have positive relationships with staff and peers and that the institution provides support for success.

Work integrated learning is also an important dimension of engagement, positively predicting both satisfaction and student learning. Developing generic graduate skills and preparing students for the workforce is increasingly seen as a vital function of universities (McLennan \& Keating, 2008, June). Other studies have noted that third year students have greater levels of work integrated learning than first years (Coates, 2010), but the present findings suggest that it is also beneficial for first year students.

A few studies have found that enriching educational experiences have a positive impact on direct measures of learning such as GPA (Campbell \& Cabrera, 2011; Pascarella et al., 2010). Here, enriching educational experiences have a very small positive impact on learning and are negatively related to satisfaction. However, this scale has unacceptable internal reliability $(\alpha=.57)$, a finding paralleled by others (Campbell \& Cabrera, 2011; Gordon et al., 2008; LaNasa, Cabrera, \& Trangsrud, 2009). Poor reliability such as this attenuates correlation coefficients (Judd \& Kenny, 1981). In addition, the scale has questionable validity, measuring a diverse range of factors. Redevelopment of this scale is needed to improve its reliability and validity. 


\section{Student engagement}

The second aim was to explore how age and mode of study affect student engagement and student outcomes. Despite the well-documented practical and emotional barriers faced by mature aged students, students aged 25 and over in this study were as satisfied as younger students were and reported similar levels of learning. Their engagement was similar to that of younger students although they reported slightly lower levels of active learning and enriching educational experiences. This finding is in contrast to Southerland (2010) who found that adult students had slightly higher levels of active learning. Older students exceeded younger students in terms of work integrated learning and academic challenge, providing further evidence for the finding that mature students use deeper learning strategies (Hoskins \& Hooff, 2005; Justice \& Dornan, 2001), an element of engagement that is captured in the academic challenge subscale.

Distance students in this study were as satisfied as campus based students but reported slightly less learning. This may be due in part to their lower levels of engagement in all areas except work integrated learning where they were significantly higher. In particular, they reported less active learning. Chen and colleagues (2008) also found distance students experienced less active learning but, in contrast to the present findings, their distance students were more engaged than campus based students in other areas.

Examination of the Active Learning items reveals that distance students and students aged 25 and over ask questions and discuss ideas at least as much as internal, younger students. However, they work less with other students, both inside and outside class. Past studies have found that mature students actively engage and interact more with staff, both on line and in the classroom, but less with their fellow students (Kasworm, 2010; Krause et al., 2005; Rabe-Hemp et al., 2009; Wasley, 2006). What is unknown is whether it is formal or informal group work they are missing. It may be due in part to course design differences, internal papers potentially incorporate more group-based activities, but it may also be due to contextual differences that inhibit older distance students' opportunities to form friendships. Firstly, older students often feel that they do not fit in well with the young students (Johnson \& Watson, 2004). Secondly, studying at home does not provide the face-to-face opportunities for collaborative learning outside of the classroom. Finally, mature students tend to have more complex full lives which leave little time, or potentially desire, to work with other students (Christie et al., 2005).

Despite differences in patterns of engagement, the finding that mature distance students are as satisfied as those on campus and feel they are learning at a similar level suggests theirs is not a second rate experience. Others have suggested that adult learners may compensate for the barriers to study with strategies such as applying broader life skills (Donaldson \& Graham, 1999), deeper learning strategies (Burton, Lloyd, \& Griffiths, 2011) or greater academic integration (Mannan, 2007). An important finding from the present study is that both older students and distance students were better able to integrate their learning with their work experiences. While other researchers have noted the conflicts between life experience and academic knowledge and the difficulties this brings for adult students (Bamber \& Tett, 2000; Henderson et al., 2009; Toynton, 2005), the current findings highlight the positive. The ability and opportunity to relate their learning to the 'real' world of work may compensate for the reduced opportunity or desire to interact with fellow students. Universities must 
build on this strength because, as Brookfield (1995) points out, the experiences of adult students are a valuable resource.

The benefits of active learning are supported in the finding that active learning predicted learning. More consideration therefore needs to be given to providing avenues and opportunities for older distance students to work with their peers on collaborative tasks through online learning systems. The sense of isolation that these students sometimes experience (Kasworm, 2010) may also be countered by such connections with peers. However, a limitation of survey findings is the tendency to obscure important individual differences. LaPointe and Reisetter's (2008) qualitative study identified two quite distinct groups of students: those who highly valued the online learning community and those who felt it was a waste of time. This, paralleled with the need for autonomy and self directed learning that is seen as central to adult learning (Cercone, 2008), suggests that students need to be given choice about participating in collaborative projects and online discussions.

\section{Departure intention}

As expected, students who have considered leaving are considerably less satisfied with their university experience and rate their learning as less. Past research on the relationship between student engagement and persistence has had mixed findings: Korzekwa (2007) found no relationship whereas Kuh et al. (2008) found that student engagement did predict persistence. This may reflect the fact that engagement is a multifaceted construct and highlights the need to examine different dimensions. The current findings suggest academic challenge, a supportive environment, and work integrated learning as particularly important aspects of engagement for encouraging persistence.

Looking specifically at mature distance students, the present study found that these students, despite their lower levels of engagement, are no more likely to have considered leaving the university than traditional students. This supports the view that differences in the engagement patterns for this group do not necessarily lead to dissatisfaction and departure. It may be that the reasons they leave are more related to their life outside the university than their experiences within it.

There is considerable evidence that shows older distance students in New Zealand do have higher first year attrition rates than younger students (Ministry of Education, 2011) and so why did this study not find such differences? One possible explanation for this is the timing of the survey: The AUSSE is completed part way through the year's second semester and therefore only includes students who have survived the initial, and often challenging, transition period of the first semester. Unlike traditional students who are transitioning from school, mature students are adding a completely new dimension to their identity and a new, time consuming and challenging activity to their lives. Many of the practical and emotional challenges that mature students face as outlined in the introduction, such as role pressures, lack of skills, anxiety, and feeling alienated within the university, are likely to manifest very early on in their enrolment. It may therefore be that older students drop out much earlier in the year and are not included in the present study. This is an important point if institutions aim to use the AUSSE data to improve the quality of their services and increase retention as is often suggested (Devlin, Coates, \& Kinzie, 2007). 


\section{Limitations and future research}

Although the authors of the NSSE claim it satisfies the conditions by which self-report surveys are valid (Kuh, 2001), there is potential for differing interpretations of questions. Chen et al. (2008) raise the possibility that distance students may interpret the questions differently because of their different context. For example, while campus students might see tutorials as "working with students on projects during class", one of the Active Learning items, would distance students see posting in online forums the same way? An additional concern is that students may interpret the response options, "sometimes", "often", and "very often", differently. Porter (2011) points out that this measure of frequency of behaviours is problematic; for example, one study showed that "very often" could be interpreted as meaning anything from 6 to 60 times per year (Pace \& Friedlander, 1982). Further research to establish the validity of these aspects of the AUSSE is required.

Other limitations suggest directions for further research. Firstly, caution must be exercised before generalising these findings. The study focuses on a single New Zealand university and, as mentioned, the sample differed slightly from the population in terms of gender, age, and other demographic factors. However, the findings from the study warrant further exploration with this population in different settings. Secondly, as mentioned earlier, the timing of the survey creates its own limitation the findings cannot tell us about the students who drop out in the first few weeks or months of study, an important group. The possibility that these are more likely to be mature students could be tested through analysis of the demographics of students who leave. Thirdly, cross sectional research by its very nature is limited: it cannot capture the important shifting patterns of engagement. There is a need for longitudinal research designs that are better able to measure the complex and changing nature of engagement. Finally, the current study suggests that mature distance students have a different pattern of engagement to traditional younger students. In-depth qualitative research is needed to explore this further and to understand why mature distance students engage differently with their studies.

\section{Conclusion}

Student engagement is well established as an important factor contributing to the success and wellbeing of students. The current study examined the engagement of mature distance students and found that this group faces additional challenges but also exhibits additional strengths. They are a highly satisfied group of students suggesting that while their experiences and engagement may be different to the traditional aged, on campus model, it is not necessarily a lesser experience. Universities would do well to build on the strengths that this group of students bring to their classes as well as work to provide them with greater opportunities to meet and form collaborative relationships with similar peers. 


\section{References}

Bamber, J., \& Tett, L. (2000). Transforming the learning experiences of non-traditional students: A perspective from higher education. Studies in Continuing Education, 22(1), 57-75. doi: 10.1080/01580379950143519

Brookfield, S. (1995). Adult learning: An overview. In A. Tuinjman (Ed.), International encyclopedia of education (pp. 375-380). Oxford: Pergamon.

Burton, K., Lloyd, M. G., \& Griffiths, C. (2011). Barriers to learning for mature students studying HE in an FE college. Journal of Further and Higher Education, 35(1), 25-36.

Bye, D., Pushkar, D., \& Conway, M. (2007). Motivation, interest, and positive affect in traditional and nontraditional undergraduate students. Adult Education Quarterly, 57(2), 141-158. doi: $10.1177 / 0741713606294235$

Campbell, C. M., \& Cabrera, A. F. (2011). How sound is NSSE?: Investigating the psychometric properties of NSSE at a public, research-extensive institution. The Review of Higher Education, 35(1), 77-103.

Cercone, K. (2008). Characteristics of adult learners with implications for online learning design. Association for the Advancement of Computing in Education Journal, 16(2), 137-159.

Chen, P., Gonyea, R., \& Kuh, G. D. (2008). Learning at a distance: Engaged or not. Innovate: Journal of Online Education, 4(3). Retrieved from http://www.innovateonline.info

Christie, H., Munro, M., \& Wager, F. (2005). 'Day students' in higher education: Widening access students and successful transitions to university life. International Studies in Sociology of Education, 15(1), 3-30. doi: 10.1080/09620210500200129

Coates, H. (2010). Development of the Australasian Survey of Student Engagement (AUSSE). Higher Education, 60(1), 1-17. doi: 10.1007/s10734-009-9281-2

Devlin, M., Coates, H., \& Kinzie, J. (2007). Using AUSSE data for enhancement. Melbourne, Australia: Australian Council for Educational Research.

DiBiase, D., \& Kidwai, K. (2010). Wasted on the young? Comparing the performance and attitudes of younger and older US adults in an online class on geographic information. Journal of Geography in Higher Education, 34(3), 299-326.

Donaldson, J. F., \& Graham, S. (1999). A model of college outcomes for adults. Adult Education Quarterly, 50(1), 24-40.

Gallacher, J., Crossan, B., Field, J., \& Merrill, B. (2002). Learning careers and the social space: Exploring the fragile identities of adult returners in the new further education. International Journal of Lifelong Education, 21(6), 493-509. doi: 10.1080/0260137022000016172

Gonyea, R. M. (2005). Self reported data in institutional research: Review and recommendations. New Directions for Institutional Research, 2005(127), 73-89.

Gordon, J., Ludlum, J., \& Hoey, J. J. (2008). Validating NSSE against student outcomes: Are they related? Research in Higher Education, 49(1), 19-39. doi: 10.1007/s11162-007-9061-8

Hartman, J., Moskal, P., \& Dziuban, C. (2005). Preparing the academy of today for the learner of tomorrow. In D. G. Oblinger \& J. L. Oblinger (Eds.), Educating the net generation (pp. 6.16.15). Washington, DC: Educause.

Henderson, R., Noble, K., \& De George-Walker, L. (2009). Transitioning into university: 'Interrupted' first year students problem-solving their way into study. Studies in Learning, Evaluation, Innovation and Development, 6(1), 51-65.

Hoskins, S., \& Hooff, J. (2005). Motivation and ability: Which students use online learning and what influence does it have on their achievement? British Journal of Educational Technology, 36(2), 177-192.

Johnson, G. C., \& Watson, G. (2004). 'Oh gawd, how am I going to fit into this?': Producing [mature] first-year student identity. Language and Education, 18(6), 474-487.

Judd, C. M., \& Kenny, D. A. (1981). Estimating the effects of social interventions. New York: Cambridge University Press.

Justice, E., \& Dornan, T. (2001). Metacognitive differences between traditional-age and nontraditional-age college students. Adult Education Quarterly, 51(3), 236-249.

Kasworm, C. E. (2010). Adult learners in a research university: Negotiating undergraduate student identity. Adult Education Quarterly, 60(2), 143-160. 
Korzekwa, A. M. (2007). An examination of the predictive validity of National Survey of Student Engagement benchmarks and scalelets. Master of Arts, University of New Mexico, Albuquerque, New Mexico.

Krause, K., \& Coates, H. (2008). Students' engagement in first-year university. Assessment \& Evaluation in Higher Education, 33(5), 493-505. doi: 10.1080/02602930701698892

Krause, K., Hartley, R., James, R., \& McInnis, C. (2005). The first year experience in Australian universities: Findings from a decade of national studies. Canberra, Australia: Department of Education, Science and Training.

Kuh, G. D. (2001). The National Survey of Student Engagement: Conceptual framework and overview of psychometric properties. Bloomington, IN: Indiana University Center for Postsecondary Research and Planning.

Kuh, G. D. (2009a). The National Survey of Student Engagement: Conceptual and empirical foundations. New Directions for Institutional Research, 141, 5-20. doi: 10.1002/ir.283

Kuh, G. D. (2009b). What student affairs professionals need to know about student engagement. Journal of College Student Development, 50(6), 683-706. doi: 10.1353/csd.0.0099

Kuh, G. D., Cruce, T. M., Shoup, R., Kinzie, J., \& Gonyea, R. M. (2008). Unmasking the effects of student engagement on first-year college grades and persistence. The Journal of Higher Education, 79(5), 540-563. doi: 10.1353/jhe.0.0019

LaNasa, S. M., Cabrera, A. F., \& Trangsrud, H. (2009). The construct validity of student engagement: A confirmatory factor analysis approach. Research in Higher Education, 50(4), 315-332. doi: 10.1007/s11162-009-9123-1

LaPointe, L., \& Reisetter, M. (2008). Belonging online: Students' perceptions of the value and efficacy of an online learning community. International Journal on E-Learning, 7(4), 641665.

Mannan, M. A. (2007). Student attrition and academic and social integration: Application of Tinto's model at the University of Papua New Guinea. Higher Education, 53(2), 147-165.

McLennan, B., \& Keating, S. (2008, June). Work-integrated learning (WIL) in Australian universities: The challenges of mainstreaming WIL. Paper presented at the ALTC NAGCAS National Symposium, Melbourne, Australia.

Mercer, J., \& Saunders, D. (2004). Accommodating change: The process of growth and development amongst a mature student population. Research in Post-Compulsory Education, 9(2), 283300.

Ministry of Education. (2011). Education counts. Retrieved 12 July, 2011, from http://www.educationcounts.govt.nz/statistics/tertiary education

Moore, K., Bartkovich, J., Fetzner, M., \& Ison, S. (2002). Success in cyberspace: Student retention in online courses. Paper presented at the $42^{\text {nd }}$ Annual Forum for the Association for Institutional Research Toronto, Canada.

Murphy, M., \& Fleming, T. (2000). Between common and college knowledge: Exploring the boundaries between adult and higher education. Studies in Continuing Education, 22(1), 7793. doi: $10.1080 / 01580379950143528$

National Survey of Student Engagement. (2011). Adjustment for part-time students on four items comprising the Level of Academic Challenge benchmark. Retrieved 18 August, 2011, from http://nsse.iub.edu/ /?cid $=405$

Nelson Laird, T. F., \& Cruce, T. M. (2009). Individual and environmental effects of part-time enrollment status on student-faculty interaction and self-reported gains. The Journal of Higher Education, 80(3), 290-314.

Pace, R. C., \& Friedlander, J. (1982). The meaning of response categories: How often is "occasionally,"“often," and "very often"? Research in Higher Education, 17(3), 267-281.

Pascarella, E. T., Seifert, T. A., \& Blaich, C. (2010). How effective are the NSSE benchmarks in predicting important educational outcomes? Change, 42(1), 16-22.

Porter, S. R. (2011). Do college student surveys have any validity? Review of Higher Education, 35(1), 45-76. doi: 10.1353/rhe.2011.0034

Rabe-Hemp, C., Woollen, S., \& Humiston, G. S. (2009). A comparative analysis of student engagement, learning, and satisfaction in lecture hall and online learning settings. Quarterly Review of Distance Education, 10(2), 207-218. 
Reay, D., Ball, S., \& David, M. (2002). "It's taking me a long time but I'll get there in the end": Mature students on access courses and higher education choice. British Educational Research Journal, 28(1), 5-19. doi: 10.1080/01411920120109711

Sitzmann, T., Kraiger, K., Stewart, D., \& Wisher, R. (2006). The comparative effectiveness of web based and classroom instruction: A meta analysis. Personnel Psychology, 59(3), 623-664.

Southerland, J. N. (2010). Engagement of adult undergraduates: Insights from the National Survey of Student Engagement. Unpublished doctoral dissertation, The University Of Utah, Salt Lake City, UT.

Stone, C. (2008). Listening to individual voices and stories: The mature-age student experience. Australian Journal of Adult Learning, 48(2), 264-290.

Tinto, V. (2006). Research and practice of student retention: What next? Journal of College Student Retention: Research, Theory and Practice, 8(1), 1-19.

Tison, E. B., Bateman, T., \& Culver, S. M. (2011). Examination of the gender-student engagement relationship at one university. Assessment \& Evaluation in Higher Education, 36(1), 27-49.

Toynton, R. (2005). Degrees of disciplinarity in equipping mature students in higher education for engagement and success in lifelong learning. Active Learning in Higher Education, 6(2), 106117.

Trowler, V., \& Trowler, P. (2010). Student engagement evidence summary. York, UK: The Higher Education Academy.

Tyler-Smith, K. (2006). Early attrition among first time elearners: A review of factors that contribute to drop-out, withdrawal and non-completion rates of adult learners undertaking elearning programmes. Journal of Online Learning and Teaching, 2(2), 73-85.

Urquhart, B., \& Pooley, J. (2007). The transition experience of Australian students to university: The importance of social support. The Australian Community Psychologist, 19(2), 78-91.

Wasley, P. (2006). Underrepresented students benefit most from 'engagement'. Chronicle of Higher Education, 53(13), A39-40.

White, S. (2008). Mothers who are student teachers: Navigating their dual roles in pre-service teacher education. Studies in Continuing Education, 30(2), 159-172. doi: $10.1080 / 01580370802102064$

\section{Word Count: 6605}




\title{
The engagement of mature distance students
}

\author{
Kahu, ER
}

2013-10-01

http://hdl.handle.net/10179/15153

22/04/2023 - Downloaded from MASSEY RESEARCH ONLINE 